\title{
Perancangan Aplikasi Panduan Pariwisata Kota Tasikmalaya pada Perangkat Bergerak Berbasis Android
}

\author{
Danial Ahmad Muslih*), Rinta Kridalukmana, Kurniawan Teguh Martono \\ Program Studi Sistem Komputer, Fakultas Teknik, Universitas Diponegoro \\ Jalan Prof. Sudharto, SH, Kampus Undip Tembalang, Semarang, Indonesia 50275
}

\begin{abstract}
Tourism is a valuable aspect of a region. The presence of the tourist areas will promote the welfare of the surrounding community. Information about the location of the tourist attractions in Tasikmalaya is still lacking and this is an obstacle for the tourists who will go sightseeing. Tasikmalaya tourism guide Application is built using Eclipse IDE with Java language. This application is created using PHP and MySql database. The design phase made is using Multimedia Development Life Cycle with UML modeling. The results obtained from this research is a tourism guide application that runs on Android operating system. The result shows that this application runs well on Ice Cream Sandwich version and more. Buttons and functions within the application has been running well with the respective functionality.
\end{abstract}

Keyword - Touris; Tasikmalaya; Eclipse; PHP; Android Application

Abstrak - Pariwisata merupakan aspek yang berharga bagi suatu daerah. Dengan adanya daerah pariwisata maka dapat memajukan kesejahteraan masyarakat sekitar. Tasikmalaya memiliki objek wisata yang banyak namun informasi mengenai letak tempat wisata di Tasikmalaya masih kurang dan hal ini menjadi kendala bagi para wisatawan yang akan pergi berwisata. Aplikasi panduan pariwisata edisi Tasikmalaya merupakan aplikasi yang dibuat menggunakan perangkat lunak Eclipse IDE, dimana bahasa pemrograman yang digunakan adalah Java, serta menggunakan bahasa pemrograman PHP, dan basis data MySQL. Tahap perancangan dilakukan dengan metode Multimedia Development Life Cycle dengan paduan pemodelan UML. Hasil yang diperoleh dari perancangan aplikasi ini adalah terwujudnya sebuah aplikasi panduan pariwisata yang berjalan pada perangkat bergerak berbasis Android. Hasil pengujian menunjukkan bahwa aplikasi ini berjalan baik pada sistem operasi android Ice Cream Sandwich. Tombol dan fungsi yang ada dalam aplikasi ini telah berjalan dengan baik sesuai dengan fungsionalitasnya masing-masing.

Kata kunci - Pariwisata; Tasikmalaya; Eclipse; PHP; Aplikasi Android

\section{PENDAHULUAN}

Pariwisata merupakan perjalanan dari suatu tempat ketempat lain, bersifat sementara, dilakukan perorangan atau kelompok, sebagai usaha mencari keseimbangan atau keserasian dan kebahagiaan dengan lingkungan dalam dimensi sosial, budaya, alam dan ilmu[1].

Manusia membutuhkan sesuatu yang dapat membuat

*) Penulis Korespondensi (Danial Ahmad Muslih)

Email : ahmad.danial7@gmail.com hidupnya lebih seimbang dan berwarna, dengan melakukan perjalanan ke suatu tempat baru dengan berbagai macam kegiatan yang bermakna dan disukai. Pariwisata dalam perkembangan seni budaya dan ekonomi juga memiliki peran yang besar, karena dengan adanya orang atau sekelompok orang yang berkunjung di suatu daerah tujuannya adalah mencari tahu sesuatu ciri khas atau keunikan daerah tersebut. Sehingga daerah tersebut dapat mengembangkan atau memunculkan makanan, kerajinan, ataupun kebudayaan yang dimiliki.

Informasi mengenai letak tempat wisata masih kurang dan hal ini menjadi kendala bagi para wisatawan yang akan pergi berwisata. Diperlukan sebuah sistem informasi geografis yang dapat mendukung kegiatan para wisatawan terutama di kota Tasikmalaya. Keberadaan tempat wisata di Kota Tasikmalaya merupakan hal yang sangat penting, namun pengetahuan para wisatawan mengenai objek pariwisata di kota Tasikmalaya masih sangat minim. Dengan adanya aplikasi pariwisata maka informasi daerah wisata dapat didapatkan dengan mudah.

Sistem informasi pariwisata kota Tasikmalaya yang ada saat ini masih berbasis web dimana sistem tersebut memiliki kekurangan yaitu sistem informasi tersebut akan maksimal jika diakses melalui desktop. Keadaan inilah yang coba dimanfaatkan untuk mempermudah wisatawan untuk mengetahui keberaadaan tempat pariwisata menggunakan teknologi pada perangkat bergerak.

Pada penelitian [8] dikembangkan aplikasi android dalam bidang pariwisata yang berisi panduan pariwisata di kota Semarang. Pengguna dapat mengetahui objek wisata apa saja yang berada di Kota semarang dan fasilitas umum apa saja yang tersedia di sekitar pengguna aplikasi. Aplikasi ini juga dapat menunjukkan rute dari lokasi pengguna aplikasi menuju objek wisata yang di inginkan. Penelitian [9] membuat aplikasi android yang berisi Informasi asrama mahasiswa Aceh yang berada di seluruh pulau Jawa. Dengan aplikasi ini, pengguna dapat mengetahui lokasi asrama Aceh yang tersebar di pulau Jawa. Aplikasi ini juga dapat menunjukkan rute dari lokasi pengguna aplikasi menuju asrama yang diinginkan. Pada penelitian ini dikembangkan aplikasi android untuk pariwisata di Kota Tasikmalaya. Melalui aplikasi ini pengguna dapat mengetahui informasi mengenai objek wisata dari video, sehingga lebih menarik. Selain itu pengguna juga bisa menyampaikan saran dan keluhan mengenai objek wisata tersebut kepada pengelola melalui pesan singkat juga $e$-mail.

\section{METODOLOGI PENELITIAN}

Metode penelitian yang digunakan adalah metode pengembangan multimedia. Karena pada aplikasi ini dibutuhkan tahapan untuk mengumpulkan data-data mengenai objek wisata, maka penggunaan metode ini dinilai sudah tepat. Pengembangan multimedia menurut Luther-Sutopo dilakukan berdasarkan 6 tahap, yaitu: concept, design, material collecting, assembly, testing, dan distribution[2]. Pada tahap design, selain menggunakan 
perancangan berbasis multimedia akan digunakan juga perancangan dengan UML (Unified Modelling Language).

Concept aplikasi bertema perancangan aplikasi pariwisata kota Tasikmalaya pada perangkat bergerak berbasis android dibuat untuk mengenalkan objek wisata yang berada di Tasikmalaya. Didalam aplikasi ini terdapat informasi tentang masing-masing objek wisata beserta galeri objek wisata tersebut sehingga pengguna mendapat informasi yang lebih menarik.

Pada tahap design dimulailah perancangan aplikasi yang disesuaikan dengan konsep yang telah dibuat sebelumnya. Perancangan aplikasi dimulai dengan membuat rancangan alur visual dari aplikasi secara keseluruhan yang nantinya akan ditampilkan. Pada tahap perancangan akan digunakan model perancangan UML dan Perancangan berbasis multimedia. UML merupakan salah satu alat bantu yang sangat handal dalam bidang pengembangan sistem berorientasi objek Karena UML menyediakan bahasa pemodelan visual yang memungkinkan pengembang sistem membuat blue print dalam bentuk yang baku[3]. Pemodelan aplikasi menggunakan UML pada perancangan aplikasi ini terdiri dari use case diagram untuk menggambarkan perilaku aplikasi, activity diagram untuk menggambarkan rangkaian aliran dari aktivitas, sequence diagram untuk menggambarkan interaksi aplikasi, dan class diagram untuk menggambarkan struktur statis class di dalam sistem. Selain itu pada perancangan aplikasi ini digunakan juga perancangan basis data dan perancangan EntityRelational Diagram (ERD).

Perancangan berbasis multimedia menggunakan perangkat storyboard dan flowchart view. Storyboard digunakan untuk multimedia linier dan flowchart view digunakan sebagai pelengkap storyboard untuk multimedia non-linier (interaktif).

Tahap material collecting dilakukan pengumpulan informasi dan foto-foto mengenai objek wisata yang berada di Tasikmalaya dengan mengunjungi objek wisata tersebut dan mengumpulkan informasi melalui jaringan internet. Foto-foto pada galeri aplikasi didapat dari internet begitu pula dengan bahan audio didapat dari internet. Video yang terdapat pada aplikasi merupakan foto-foto galeri dan audio yang diolah menggunakan perangkat lunak kdenlive.

Tahap assembly merupakan tahap pembuatan seluruh objek multimedia. Pembuatan aplikasi berdasarkan antarmuka, diagram alir, struktur navigasi, atau diagram objek yang berasal dari tahap desain.Kebutuhan dalam tahap assembly antara lain API dan Java. API (Application Programming Interface) adalah sekumpulan perintah, fungsi, dan protokol yang dapat digunakan oleh programmer saat membangun perangkat lunak untuk sistem operasi tertentu. API memungkinkan programmer untuk menggunakan fungsi standar untuk berinteraksi dengan sistem operasi lain [4]. Java merupakan bahasa pemograman yang bersifat umum dan secara khusus didesain untuk memanfaatkan dependensi implementasi seminimal mungkin, karena fungsionalitasnya yang memungkinkan aplikasi java mampu berjalan di beberapa platform sistem operasi yang berbeda[5].

Tahap testing dilakukan setelah tahap assembly selesai dan seluruh data telah dimasukkan. Pertama-tama dilakukan pengujian untuk memastikan apakah hasilnya seperti yang diinginkan. Pada tugas akhir ini tahap pengujian yang dilakukan adalah metode black box yaitu menguji fungsionalitas dari perangkat lunak saja tanpa harus mengetahui struktur internal program (source code).

\section{HASIL DAN PEMBAHASAN}

\section{A. Konsep}

Konsep aplikasi bertema perancangan aplikasi pariwisata pada perangkat bergerak berbasis android edisi Tasikmalaya dibuat untuk mengenalkan objek wisata yang berada di Tasikmalya. Didalam aplikasi ini terdapat informasi tentang masing-masing objek wisata beserta foto-foto juga video objek wisata tersebut sehingga pengguna mendapat informasi yang lebih menarik. Aplikasi ini dapat digunakan oleh semua kalangan, dengan harapan aplikasi ini bisa menjadi referensi berlibur agi siapa saja yang akan berlibur di Tasikmalaya.

\section{B. Perancangan UML}

Pemodelan aplikasi menggunakan UML (Unified Modelling Language) pada perancangan aplikasi ini terdiri dari use case diagram, activity diagram, sequence diagram, dan class diagram. Selain itu pada perancangan aplikasi ini digunakan juga perancangan basis data dan perancangan Entity Relational Diagram (ERD).

Use-Case menggambarkan apa saja yang dapat dikerjakan oleh aktor sehingga use-case digunakan untuk menggambarkan perilaku sistem sebagai bentuk respon terhadap pengguna. Gambar 1 menunjukkan use-case pada aplikasi panduan pariwisata yang dibuat. Pada aplikasi panduan pariwisata ini terdapat dua aktor yaitu pengguna

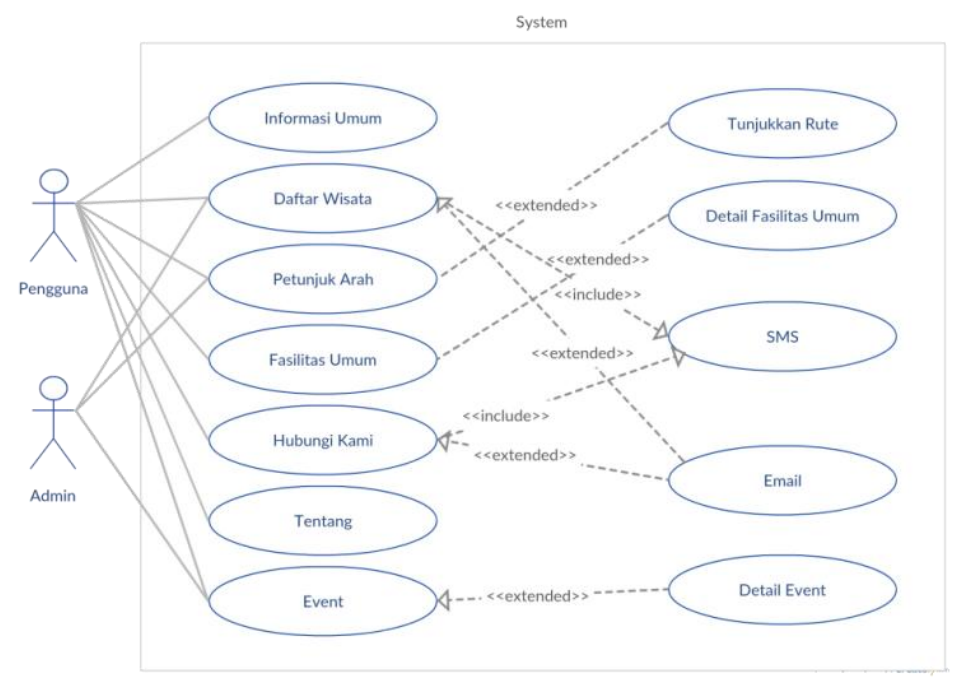

dan admin.

Gambar 1 Use case diagram aplikasi

Activity Diagram menggambarkan berbagai alir aktivitas dalam sistem yang sedang dirancang, bagaimana masing-masing alir berawal, decision yang mungkin terjadi, dan bagaimana mereka berakhir. Activity Diagram juga dapat menggambarkan proses paralel yang mungkin terjadi pada beberapa eksekusi. Gambar 2 menunjukkan activity diagram pada menu penunjuk arah. 


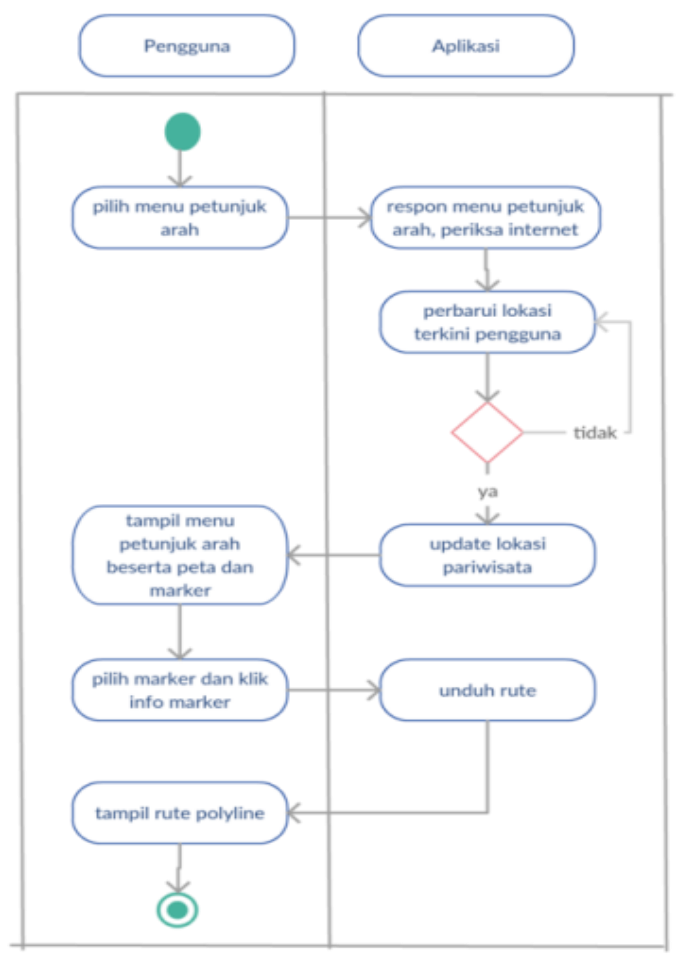

Gambar 2 Activity diagram penuntuk arah

Sequence Diagram menggambarkan interaksi antar objek di dalam dan di sekitar sistem (termasuk pengguna, display, dan sebagainya) berupa message yang digambarkan terhadap waktu. Sequence Diagram terdiri atar dimensi vertikal (waktu) dan dimensi horizontal (objek-objek yang terkait). Sequence Diagram biasa digunakan untuk menggambarkan skenario atau rangkaian langkah-langkah yang dilakukan sebagai respons dari sebuah event untuk menghasilkan output tertentu. Diawali dari apa yang men-trigger aktivitas tersebut, proses dan perubahan apa saja yang terjadi secara internal dan output apa yang dihasilkan.

Class diagram memberikan gambaran sistem secara statis. Class diagram digunakan untuk menampilkan kelaskelas dan paket-paket yang ada di dalam sistem serta menampilkan relasi antar kelas-kelas tersebut.

Dalam perancangan basis data aplikasi panduan pariwisata edisi kota Tasikmalaya ini akan dibuat dalam 3 tabel. Tabel-tabel tersebut adalah tabel user, tabel objek wisata, dan tabel event. Tabel 1 menunjukkan struktur dan deskripsi dari tabel objek wisata.

Tabel 1 Struktur tabel Objek Wisata

\begin{tabular}{llll}
\hline \multicolumn{1}{c}{ Atribute } & \multicolumn{1}{c}{ Tipe Data } & Panjang & Keterangan \\
\hline$\underline{\text { id }}$ & Int & 5 & primary key \\
nama & varchar & 50 & \\
no_hp & varchar & 13 & \\
email & varchar & 50 & \\
Lat & double & & \\
Lng & double & & \\
\hline
\end{tabular}

Memperhatikan data serta informasi yang digunakan dalam proses pembangunan aplikasi ini, maka dibangun sebuah desain basis data dengan menggunakan tools Entity Relational Diagram (ERD).

\section{Perancangan Multimedia}

Perancangan berbasis multimedia menggunakan perangkat storyboard/antarmuka dan flowchart view. Storyboard digunakan untuk multimedia linier dan flowchart view digunakan sebagai pelengkap storyboard

Copyright (C)2017, JTSiskom, e-ISSN:2338-0403 untuk multimedia non-linier (interaktif). Gambar 3 menunjukkan storyboard menu utama.

\begin{tabular}{|c|c|c|}
\hline \multirow{12}{*}{$\begin{array}{c}\text { Tampilan } \\
\text { Menu Utama }\end{array}$} & & Judul \\
\hline & & Sub judul \\
\hline & & Informasi umum \\
\hline & & Daftar Wisata \\
\hline & & Petunjuk Arah \\
\hline & & Fasilitas Umum \\
\hline & & Hubungi Kami \\
\hline & & Tentang \\
\hline & & Event \\
\hline & Text & Judul Aplikasi, Sub Judul Aplikasi, Event \\
\hline & ImageButton & $\begin{array}{l}\text { Informasi Umum, Daftar Wisata, Petunjuk Arah, } \\
\text { Fasilitas Umum, Hubungi Kami, Tentang }\end{array}$ \\
\hline & Link & $\begin{array}{l}\text { halaman informasi umum, halaman daftar wisata, } \\
\text { halaman Petunjuk arah, halaman fasilitas umum, } \\
\text { halaman Hubungi Kami, halaman Tentang }\end{array}$ \\
\hline
\end{tabular}

Gambar 3 Storyboard menu utama

\section{Pengumpulan Bahan}

Pengumpulan materi aplikasi merupakan tahap mengumpulkan bahan seperti teks, gambar, suara, pembuatan citra grafik, foto dan lain-lain yang diperlukan untuk tahap pembuatan aplikasi. Pada proses pembuatan aplikasi panduan pariwisata berbasis Android ini bahanbahan yang diperlukan antara lain adalah teks, foto,dan video.

\section{E. Pembuatan Aplikasi}

Pembuatan aplikasi dilakukan dengan membuat setiap layout sebagai activity, dimulai dari activity menu utama dan seterusnya. Pembuatan disesuaikan dengan rancangan aplikasi yang telah dibuat serta menggunakan bahan yang telah di kumpulkan pada tahapan pengumpulan bahan. Adapun hasil pembuatan aplikasi yang ditampilkan tersebut adalah pembuatan aplikasi untuk activity menu utama, activity daftar wisata, activity petunjuk arah, dan pembuatan halaman admin. Berikut hasil pembuatan aplikasi untuk masing-masing activity tersebut.

Pada activity menu utama terdiri dari beberapa tombol. Tombol pada activity ini diberikan background gambar sehingga tampilan tombol tidak seperti tombol yang biasa. Gambar 4 berikut adalah tampilan saat program dijalankan.

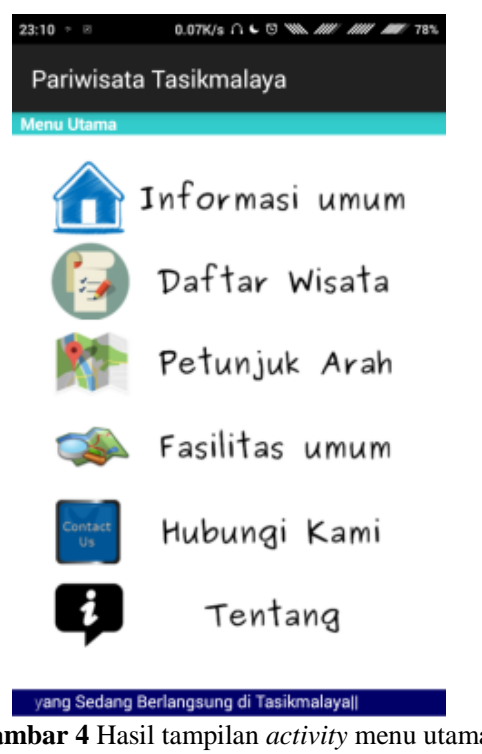

Proses selanjutnya adalah membuat activity menu daftar wisata. Pada activity ini terdapat empat buah layout yaitu layout wisata alam, wisata budaya, wisata sejarah, 
dan wisata religi. pada masing-masing layout akan terdapat daftar objek wisata sesuai kategori yang terdapat di Tasikmalaya. Gambar 5 menunjukkan tampilan dari menu daftar wisata.

\begin{tabular}{|c|c|}
\hline Daftar Wisata & Daftar Wisata \\
\hline WISATA BUDAYA & WISATA SEJAF WISATA BUDAYA \\
\hline 1. Gunung Galunggung & 1. Bumi Rongsok \\
\hline 2. Pantai Cipatujah & 2. Musium Sukapura \\
\hline 3. Pantai Karang Tawulan & 3. Situs Geger Hanjuang \\
\hline 4. Pantai Sindang Kerta & 4. Situs Gua Malawang \\
\hline 5. Situ Gede & 5. Situs Joglo dan Gua Sarongge \\
\hline 6. Situ Sanghiyang & 6. Situs Kabuyutan Nagaratengah \\
\hline \multirow[t]{4}{*}{ 7. Curug Dengdeng } & 7. Situs Kaputihan \\
\hline & 8. Situs Klasik Denuh \\
\hline & 9. Situs Sodonghilir \\
\hline & 10. Situs Walahir \\
\hline
\end{tabular}

Gambar 5 Hasil tampilan activity daftar wisata

Proses pembuatan selanjutnya adalah pembuatan activity menu petunjuk arah. Menu ini terdiri dari dua objek yaitu satu objek teks untuk sub judul dan satu objek google map. Penggunaan GoogleMap merupakan komponen yang sangat penting. Oleh karena itu yang harus dilakukan pertama kali yaitu mengimplentasikan GoogleMap API versi 2. Penggunaan GoogleMap API key merupakan salah satu yang harus diterapkan dalam aplikasi agar bisa menggunakan GoogleMap. Gambar 6 menunjukkan tampilan menu petunjuk arah.

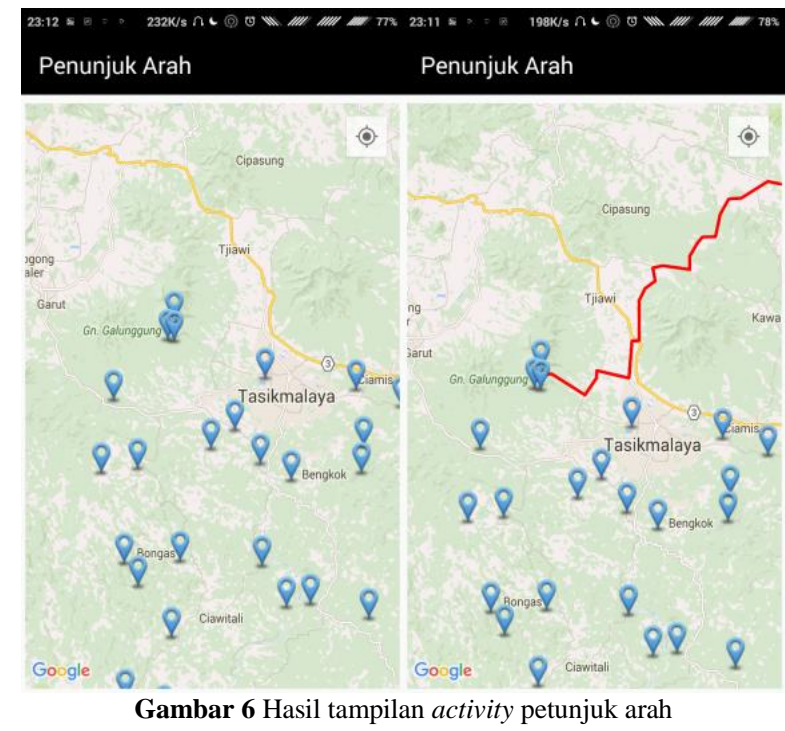

Saat pengguna memilih menu petunjuk jalan, sistem akan menampilkan map dengan marker yang menunjukkan tempat pariwisata yang ada di Tasikmalaya. Jika pengguna memilih salah satu marker, sistem akan menunjukkan nama tempat tersebut beserta keterangan untuk menekan tombol jika ingin mengetahui rute dari tempat pengguna berada ke tempat yang ditunjukkan marker tersebut.

Proses terakhir dari pembuatan aplikasi panduan pariwisata ini adalah membuat halaman administrasi. Halaman administrasi digunakan untuk menyunting database yang digunakan pada aplikasi ini. Dalam pembuatan halaman administrasi, digunakan JSON (Java Script Object Notation) dan juga PHP untuk membuat halaman web. PHP adalah sebuah bahasa pemograman yang berjalan dalam sebuah web-server (server side)[6]. JSON yaitu format pertukaran data yang ringan, mudah dibaca dan ditulis oleh manusia, serta mudah diterjemahkan dan dibuat (generate) oleh komputer[7]. Basis data aplikasi ini menggunakan MySQL. MySQL adalah sebuah server basis data open source yang paling populer. MySQL umumnya digunakan bersamaan dengan skrip PHP untuk membuat aplikasi server yang dinamis dan powerful[10].

\section{F. Pengujian Aplikasi}

Tujuan utama dari pengujian aplikasi yaitu untuk mengetahui dan memastikan bahwa aplikasi sesuai dengan perancangan yang telah dibuat sebelumnya sehingga aplikasi tidak memiliki kesalahan dan siap untuk digunakan. Pada tugas akhir ini tahap pengujian yang dilakukan adalah metode black box yaitu menguji fungsionalitas dari perangkat lunak saja tanpa harus mengetahui struktur internal program (source code).Tahap ini berisi serangkaian pengujian fungsi dan tombol pada Aplikasi.

Pengujian aplikasi ini terdiri dari proses Pengujian Menu Umum, menu Objek Wisata, menu petunjuk arah, menu fasilitas umum, menu hubungi kami, menu tentang, proses mengirim sms, proses mengirim Email, dan proses menjalankan video. Tingkat keberhasilan pengujian, diukur dari terpenuhinya spesifikasi kebutuhan dan desainaplikasi. Untuk pengujian black box yang ditampilkan antara lain adalah pengujian tombol fasilitas umum, pengujian tombol objek wisata, dan pengujian halaman administrasi.

Pengujian tombol fasilitas umum merupakan pengujian untuk mencoba menampilkan halaman fasilitas umum dan mencoba beberapa hal yang bisa terjadi pada menu fasilitas umum. Berikut hasil pengujian menu fasilitas umum dilihat pada tabel 2.

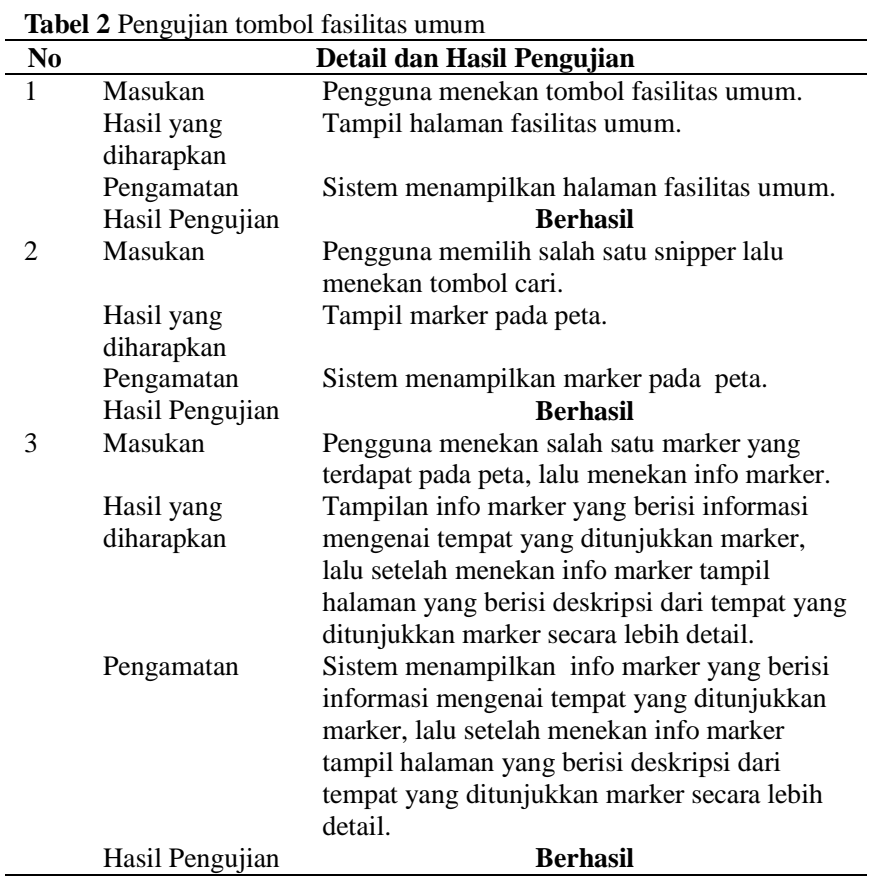

Pengujian tombol objek wisata merupakan pengujian untuk mencoba menampilkan halaman objek wisata dan mencoba beberapa hal yang bisa terjadi pada menu objek wisata. Berikut hasil pengujian menu objek wisata dilihat pada tabel 3 . 
Tabel 3 Pengujian halaman administrasi

\begin{tabular}{|c|c|c|}
\hline No & & Detail dan Hasil Pengujian \\
\hline \multirow[t]{4}{*}{1} & Masukan & $\begin{array}{l}\text { Pengguna menekan salah satu tombol objek } \\
\text { wisata pada menu daftar wisata. }\end{array}$ \\
\hline & $\begin{array}{l}\text { Hasil yang } \\
\text { diharapkan }\end{array}$ & $\begin{array}{l}\text { Tampil halaman objek wisata sesuai dengan } \\
\text { pilihan pengguna. }\end{array}$ \\
\hline & Pengamatan & $\begin{array}{l}\text { Sistem menampilkan halaman objek wisata } \\
\text { sesuai dengan pilihan pengguna. }\end{array}$ \\
\hline & Hasil Pengujian & Berhasil \\
\hline \multirow[t]{3}{*}{2} & Masukan & $\begin{array}{l}\text { Pengguna menekan tombol play pada video } \\
\text { yang tersedia. }\end{array}$ \\
\hline & $\begin{array}{l}\text { Hasil yang } \\
\text { diharapkan }\end{array}$ & Video mulai berjalan perputar. \\
\hline & $\begin{array}{l}\text { Pengamatan } \\
\text { Hasil Pengujian }\end{array}$ & $\begin{array}{c}\text { Sistem mulai memutar video. } \\
\text { Berhasil }\end{array}$ \\
\hline \multirow[t]{4}{*}{3} & Masukan & Pengguna menekan gambar. \\
\hline & $\begin{array}{l}\text { Hasil yang } \\
\text { diharapkan }\end{array}$ & $\begin{array}{l}\text { Tampil halaman berisi gambar pada mode } \\
\text { full screen. }\end{array}$ \\
\hline & Pengamatan & $\begin{array}{l}\text { Sistem menampilkan gambar secara penuh } \\
\text { (full screen) }\end{array}$ \\
\hline & Hasil Pengujian & Berhasil \\
\hline \multirow[t]{4}{*}{4} & Masukan & Pengguna menekan tombol SMS. \\
\hline & $\begin{array}{l}\text { Hasil yang } \\
\text { diharapkan }\end{array}$ & Tampil halaman kirim SMS. \\
\hline & Pengamatan & Sistem menampilkan halaman kirim sms. \\
\hline & Hasil Pengujian & Berhasil \\
\hline \multirow[t]{7}{*}{5} & Masukan & Pengguna menekan tombol Email. \\
\hline & Hasil yang & Tampilan pilihan untuk membuka Email \\
\hline & diharapkan & kemudian aplikasi berpindah ke aplikasi \\
\hline & & $\begin{array}{l}\text { Email yang terdapat pada perangkat bergerak } \\
\text { dengan kolom tujuan dan tembusan yang } \\
\text { terisi. }\end{array}$ \\
\hline & Pengamatan & Sistem menampilkan pilihan untuk membuka \\
\hline & & $\begin{array}{l}\text { Email kemudian aplikasi berpindah ke } \\
\text { aplikasi Email yang terdapat pada perangkat } \\
\text { bergerak dengan kolom tujuan dan tembusan } \\
\text { yang terisi. }\end{array}$ \\
\hline & Hasil Pengujian & Berhasil \\
\hline
\end{tabular}

Pengujian halamn administrasi merupakan pengujian untuk mencoba beberapa hal yang bisa terjadi pada halaman administrasi. Berikut hasil pengujian halaman administrasi dilihat pada tabel 4 .

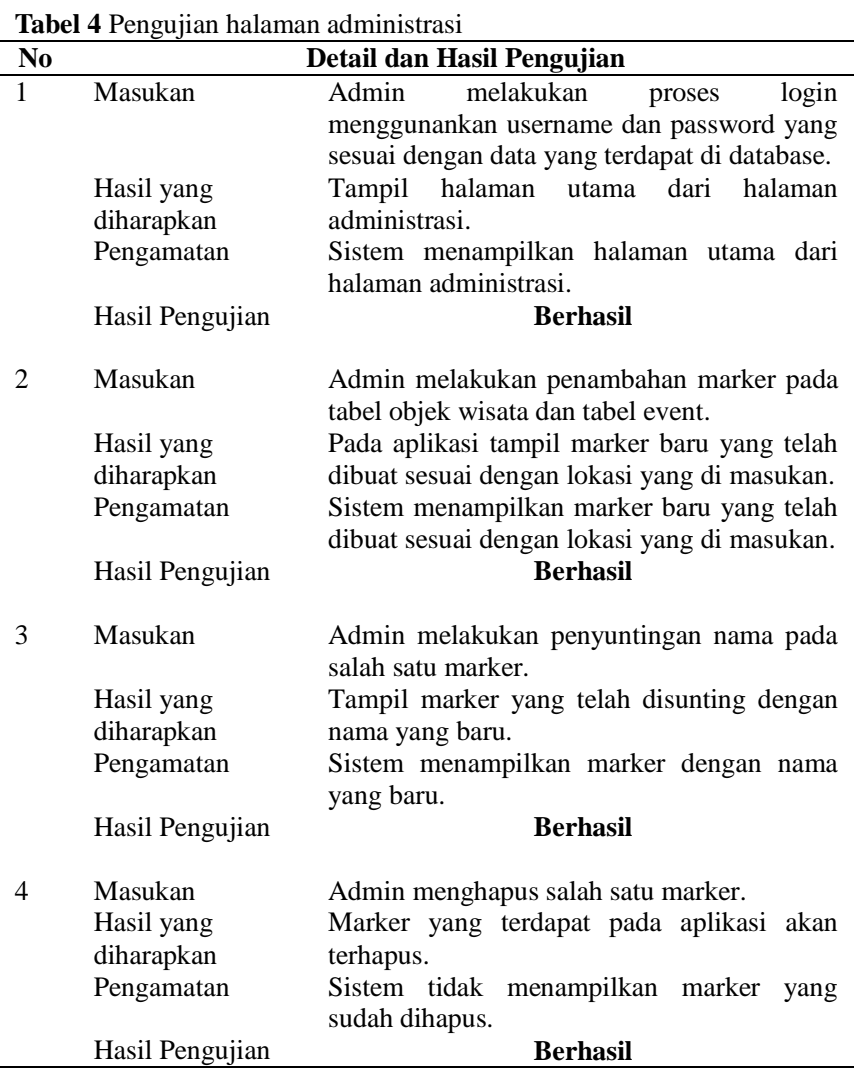

Pengujian Aplikasi dilakukan menggunakan smartphone dengan sistem operasi android. Berikut beberapa daftar smartphone yang digunakan untuk menguji Aplikasi Panduan Pariwisata Edisi Kota Tasikmlaya. Tabel 5 menunjukkan spesifikasi smartphone yang digunakan untuk menguji aplikasi.

Tabel 5 Spesifikasi Smartphone Pengujian Aplikasi Pariwisata

\begin{tabular}{|c|c|c|c|c|}
\hline No & Jenis & $\begin{array}{c}\text { Resolusi } \\
\text { Layar }\end{array}$ & OS & Keterangan \\
\hline 1 & Xiaomi Redmi 2 & $720 \times 1280$ & Kit Kat & Ok \\
\hline 2 & $\begin{array}{l}\text { Samsung Galaxy } \\
\text { Tab } 4 \text { SM-T231 }\end{array}$ & $800 \times 1280$ & Kit Kat & Ok \\
\hline 3 & Himax Polymer 2 & $540 \times 960$ & Lollipop & Ok \\
\hline 4 & Lenovo A390 & $480 \times 800$ & $\begin{array}{l}\text { Ice Cream } \\
\text { Sandwich }\end{array}$ & Ok \\
\hline 5 & Huawei T1-701u & $600 \times 1024$ & Kit Kat & $\mathrm{Ok}$ \\
\hline 6 & Asus Zenfone $4 \mathrm{~s}$ & $480 \times 854$ & Kit Kat & $\mathrm{Ok}$ \\
\hline 7 & Asus Zenfone 4 & $480 \times 800$ & Jelly Bean & $\mathrm{Ok}$ \\
\hline
\end{tabular}

Pengujian pada perangkat bergerak juga memperoleh hasil spesifikasi minimal untuk menjalankan aplikasi Panduan Pariwisata Edisi Kota Tasikmalaya adalah sebagai berikut:

1. Sistem Operasi Android Ice Cream Sandwich

2. Prosesor ARM Cortex-A9 $1.0 \mathrm{GHz}$

3. Ukuran Layar 480x800 pixel

Global Positioning System (GPS) merupakan komponen yang sangat penting dalam aplikasi ini. Dalam penggunaannya GPS akan mencari posisi dari pengguna sehingga akan menampilkannya diatas peta GoogleMap. Pengujian dilakukan dengan membandingkan keakuratan antara handheld GPS sebagai acuan modul GPS akurat dengan perangkat bergerak berbasis android. Adapun hanheld GPS yang digunakan adalah garmin etrex 10 sedangkan perangkat bergerak berbasis android yang digunakan adalah xiaomi redmi 2 dan perangkat lunak GPS Test sebagai perangkat lunak penunjang. Tempat dilakukanya percobaan antara lain tempat terbuka, tempat yang ditumbuhi pohon yang cukup rimbun, dan di dalam ruangan. Kondisi cuaca pada saat dilakukan percobaan adalah cerah dan tidak berawan.

\begin{tabular}{|c|c|c|c|c|}
\hline No & Lokasi & $\begin{array}{c}\text { Garmin Etrex } \\
10\end{array}$ & Android & Selisih \\
\hline 1 & $\begin{array}{l}\text { Belakang FIB } \\
\text { Undip }\end{array}$ & $7^{\circ} 02^{\prime} 56,5^{\prime \prime}$ & $7^{\circ} 02^{\prime} 56,707^{\prime \prime}$ & $0,207 ”$ \\
\hline $\begin{array}{l}2 \\
3\end{array}$ & Depan RSND & $7^{\circ} 02^{\prime} 51,3$ '” & $7^{\circ} 02^{\prime} 51,208^{\prime \prime}$ & $0,092 ”$ \\
\hline & $\begin{array}{l}\text { Fakultas MIPA } \\
\text { Undip }\end{array}$ & $7^{\circ} 02 ' 52,7^{\prime \prime}$ & $7^{\circ} 02^{\prime} 52,475^{\prime \prime}$ & $0,225^{\prime \prime}$ \\
\hline 4 & Dalam rumah & $7^{\circ} 03$ '22, $1^{\prime \prime}$ & $7^{\circ} 03 ' 22,373^{\prime \prime}$ & $0,273 "$ \\
\hline
\end{tabular}

Tabel 6 memperlihatkan data hasil pengujian akurasi latitude. Hasil dari pengujian keakuratan latitude GPS antara handheld GPS dengan perangkat bergerak android menunjukkan bahwa rata-rata selisihyang dihasilkan antara kedua perangkat adalah sebesar 0,14925". Selisih terendah didapatkan saat lokasi pengujian dilakukan di depan RSND dengan nilai selisih sebesar 0,092". Sedangkan selisih tertinggi didapatkan saat lokasi pengujian dilakukan di dalam rumah dengan nilai selisih sebesar 0,273".

\begin{tabular}{|c|c|c|c|c|}
\hline No & Lokasi & Garmin Etrex 10 & Android & Selisih \\
\hline 1 & $\begin{array}{l}\text { Belakang FIB } \\
\text { Undip }\end{array}$ & $110^{\circ} 26^{\prime} 14,1^{\prime \prime}$ & $110^{\circ} 26^{\prime} 14,176^{\prime \prime}$ & $0.076 "$ \\
\hline 2 & Depan RSND & $110^{\circ} 26^{\prime} 42,2^{\prime \prime}$ & $110^{\circ} 26^{\prime} 42,164^{\prime \prime}$ & $0,036^{\prime \prime}$ \\
\hline 3 & $\begin{array}{l}\text { Belakang } \\
\text { Fakultas } \\
\text { MIPA Undip }\end{array}$ & $110^{\circ} 26^{\prime} 30,8^{\prime \prime}$ & $110^{\circ} 26^{\prime} 31,095^{\prime \prime}$ & 0,295 " \\
\hline 4 & Dalam rumah & $110^{\circ} 26^{\prime} 38,0^{\prime \prime}$ & $110^{\circ} 26^{\prime} 37,769^{\prime \prime}$ & $0,231 ”$ \\
\hline
\end{tabular}


Tabel 7 memperlihatkan data hasil pengujian akurasi longitude. Hasil dari pengujian keakuratan longitude GPS antara handheld GPS dengan perangkat bergerak android menunjukkan bahwa rata-rata selisih yang dihasilkan antara kedua perangkat adalah sebesar 0,1595". Selisih terendah didapatkan saat lokasi pengujian dilakukan di depan RSND dengan nilai selisih sebesar 0,036". Sedangkan selisih tertinggi didapatkan saat lokasi pengujian dilakukan di belakang Fasuktas MIPA Undip dengan nilai error sebesar 0,295".

\section{IV.PENUTUP}

Dari hasil pengujian dan analisis Aplikasi Panduan Pariwisata pada Perangkat Bergerak Berbasis Android Edisi Kota Tasikmalaya maka dapat disimpulkan bahwa tombol-tombol dan fungsi-fungsi yang terdapat pada aplikasi dapat berfungsi dengan baik dan sesuai dengan fungsionalitasnya masing-masing. Aplikasi Panduan Pariwisata pada Perangkat Bergerak Berbasis Android Edisi Kota Tasikmalaya dapat digunakan pada perangkat bergerak dengan spesifikasi minimum sistem operasi Ice Cream Sandwich. Tingkat akurasi antara handheld GPS dan perangkat bergerak berbasis android tidak jauh berbeda, hanya saja perangkat bergerak berbasis android memerlukan fix time yang lebih banyak. GPS akan lebih akurat ketika digunakan berada di ruang terbuka.

Berdasarkan pengujian terhadap Aplikasi Panduan Pariwisata pada Perangkat Bergerak Berbasis Android Edisi Kota Tasikmalaya yang telah dibuat, dapat diberikan beberapa saran antara lain aplikasi Panduan Pariwisata pada Perangkat Bergerak Berbasis Android Edisi Kota Tasikmalaya ini dapat dikembangkan lebih lanjut dengan membuat sistem yang mencakup wilayah secara nasional dapat memberikan saran kepada wisatawan. Penggunaan Eclipse dalam membuat Aplikasi Panduan Pariwisata pada Perangkat Bergerak Berbasis Android Edisi Kota Tasikmalaya harus mempertimbangkan masalah sumberdaya perangkat bergerak, terutama pada ukuran layar. Sebab ada banyak model smartphone dengan berbagai ukuran layar. Jadi dalam mendesain harus menyesuaikan ukuran layar yang paling kecil.Perlu dilakukan penelitian lebih lanjut mengenai bagaimana membuat agar Aplikasi Panduan Pariwisata dapat diterapkan lintas sistem operasi seperti iOS dan Windows phone.

\section{DAFTAR PUSTAKA}

[1] H. Kodyat, 1996, "Sejarah Pariwisata dan Perkembanganya di Indonesia", Jakarta, PT Gramedia Pustaka Utama, Jakarta.

[2] Sutopo, Ariesto Hadi, "Multimedia Interaktif dengan Flash", Graha Ilmu, Yogyakarta, 2003.

[3] Sugiharti. Yuni, 2012, "Analisa dan Perancangan UML Generated VB6", Graha Ilmu, Jakarta

[4] Fauzan, Abd. Charis, "Google Maps API : Teori Pengantar"http://www.charisfauzan.net/2015/09/googl e-maps-api-teori-pengantar.html, 9 Februari 2016, 07.12 WIB.

[5] Abdul Kadir. 2004. "Dasar Pemrograman Java 2". Andi. Yogyakarta.

[6] Solichin, Achmad, "Pemrograman Web dengan PHP dan MySQL", Jakarta, 2009.

[7] Pengenalan JSON, http://json.org/json-id.html, 27 Juni 2016, 20.47 WIB.

[8] Richard. RFS, "Implementasi Sistem Informasi Geografis Daerah Pariwisata Kota Semarang Berbasis Android Dengan Global Positioning System (GPS)". Jurnal Teknologi dan Sistem Komputer, vol.2, no.1, pp. 96-109, Januari 2014.

[9] Alwi. Augusra, "Sistem Informasi Geografis Asrama Mahasiswa Aceh Berbasis LBS (Location Based Service) Saweue Syedara", Jurnal Teknologi dan Sistem Komputer, vol.3, no.1, pp. 8-12, Januari 2015.

[10] Nugroho, Bunafit, PHP dan MySQL dengan Editor Dreamweaver MX, Penerbit Andi, Yogyakarta, 2004. 